\title{
Javanese Culture Maintenance at Dhoplang Traditional Culinary Market, Wonogiri, to Support Plasticless Society
}

\author{
Wiwiek Sundari* \\ Faculty of Humanities, Diponegoro University, Semarang, Indonesia.
}

\begin{abstract}
As part of their creation as social creature, culture represents human being complex system of thought and practice. When people -as their creator- leave a culture, it becomes history. To maintain a culture, people should continuously use and keep them in their daily life as their cultural identity and part of their civilization. This research shows how a particular Javanese community keep their culture by holding a Javanese traditional culinary market at Dhoplang, Wonogiri, exposing Javanese traditional cuisine, clothing, language and local wisdom of environment friendly by using various leaves as wrapping to support plasticless society. It is also done to support Wonogiri tourism by obtaining more income from the vistitors for local people and government.
\end{abstract}

\section{Research Background}

Javanese culture, covering the thought, the way of life, the language, the clothing, the food and beverage as well as the local wisdom, should be kept by the Javanese ethnic themselves -and Indonesian people repsesenting country owning the culture as part of any other cultures- by keep using and passing it into the next generation. Javanese people should be aware that modernization might threaten their culture by switching, shifting and replacing it with the new and modern culture that makes it becomes history, studied by their descendant in history book or museum.

What commonly trigger the phenomenon of culture shift is the emerging popular culture adorned by the new generation replacing their culture as it considered to be old fashion or out of date. As a result, there is a decline in the Javanese culture usage frequency along with the number of the people owning, using and keeping due to the negative attitude toward the culture. Not many of Javanese youth nowadays use Javanese language, wear Javanese clothing, consume Javanese food and beverage, or even think and live like Javanese. More and more new generation today are following western culture like the American, the British or the European or even eastern culture like the Japanese or the Korean that were considered to be more popular, socially beneficial, or economically

*Corresponding author : wiwieksundari@lecturer.undip.ac.id 
profitable that Javanese culture. It is ironic to see and know the culture were studied and kept by foreigners interested in it.

\section{Theoretical Background}

Javanese culture is Javanese people way of thinking and life, enabling them holding their life from the ancient era until today as their culture identity and civilization. Javanese language as part of Javanese culture is used as communication tool among Javanese people in three levels of language politeness -Ngoko, Madya, Krama, Krama Inggil- as their cultural identity and civilization.

Since culture and language can be shifted, replaced or dead, the threat should be care-handled. The main factor of the threat is the decline of the number of the culture owner and language user due to various factors such us it is being considered as less popular, less beneficial, or less profitable than other culture and language. Therefore, only small amout of Javanese people still think and live the way Javanese people think and live, and only limited number of Javanese people still speak Javanese language with its three level of language politeness. That threat can be worsen when the culture lost their owner and the language lost their user like that of Roman civilization and Latin language. As a historical culture and language, both of them can be used or even maintained by others like Javanese culture is maintained and Javanese language is spoken by foreigners such us the Dutch, the Australian, and the Japanese.

Culture and language shift, extinction and dead happens as it is only used and preserved by the minorities (in number and area). Thus, it is only used and posessed by their community. Politic, economy and social changes can also change people's attitude toward the culture and language that reduce the culture and language value, usage and respect [1].

Some of the ways to keep culture and language are maintaining its life, supporting its usage and passing it onto the next generation. As one of the writer's researchs [2] related to Javanese language and culture maintenance within Java region, this research shows how Wonogiri people maintain Javanese culture and language by using, support, and passing it in a particular event named Dhoplang Javanese Traditional Culinary Market, providing visitors with Javanese traditional cuisine with traditional eco-frinedly wrapping to support plasticless society where buyers and sellers are obliged to wear Javanese clothing and use Javanese language and even use traditional currency made of bamboo.

\section{Research Methodology}

This research is done in two major steps. A field research is done by visiting Dhoplang Javanese Traditional Culinary Market, Desa Pandan, Kecamatan Slogohimo, Kabupaten Wonogiri which is open everyday from 6 a.m to 9 p.m. The researchers took 4 (four) samples for 8 (eight) research objects from the market using Random Sampling Technique [3] to explain its morphology and semantic name background.

The researcher also took 3 (three) research subjects in the form of 2 (two) sellers and 1 (one) buyer in the market using Random Sampling Technique [3] to see how they dress and speak Javanese language in the process of Documentation and Interview using Participatory Method [4] to know whether they still keep Javanese culture and language and what is their reason of maintaining it. The researchers also dig more information to the informant by giving Questionnaire to see their culture and language background to support the final conclusion of this research.

Meanwhile, the information obtained from the informants is analized using 7 (seven) cultural universals of language, technology system, livelihood system, social organization, 
knowledge, religion and art [5]. It is also analized using of Culture and Language Maintenance Theory [1, 6, 7] to know whether (1) the informants had already maintain Javanese culture and language or not, (2) how they maintain Javanese culture and language, and (3) why they maintain Javanese culture and language.

\section{Finding and Discussion}

\subsection{Finding}

From the field reserach, the researchers found 4 (four) Javanese culture respresentation in Dhoplang Javanese Traditional Culinary Market, Wonogiri, covering Javanese traditional food and beverage names, clothing, language, wrapping, eating utensil, foodware, and furniture for eating as follows.

Table 1. Research Finding

\begin{tabular}{|c|c|c|c|c|c|c|c|}
\hline Food & $\begin{array}{c}\text { Beverag } \\
\text { e }\end{array}$ & $\begin{array}{c}\text { Clothin } \\
\mathrm{g}\end{array}$ & $\begin{array}{c}\text { Languag } \\
\mathrm{e}\end{array}$ & $\begin{array}{c}\text { Wrappin } \\
\mathrm{g}\end{array}$ & $\begin{array}{c}\text { Eating } \\
\text { Utensi } \\
\quad 1\end{array}$ & $\begin{array}{c}\text { Foodwar } \\
\text { e }\end{array}$ & $\begin{array}{c}\text { Furnitur } \\
\text { e }\end{array}$ \\
\hline $\begin{array}{c}\text { Gati } \\
\text { (made } \\
\text { of } \\
\text { sesame } \\
\text { ) }\end{array}$ & $\begin{array}{l}\text { Bajigur } \\
\text { (hot } \\
\text { ginger } \\
\text { with } \\
\text { coconut } \\
\text { milk }\end{array}$ & $\begin{array}{c}\text { Blangko } \\
\text { n (head } \\
\text { piece } \\
\text { for } \\
\text { Male) }\end{array}$ & $\begin{array}{l}\text { Ngoko } \\
\text { (among } \\
\text { sellers) }\end{array}$ & $\begin{array}{c}\text { banana } \\
\text { leave }\end{array}$ & $\begin{array}{l}\text { Piring } \\
\text { (bamb } \\
\text { oo } \\
\text { plaited } \\
\text { plate) }\end{array}$ & $\begin{array}{c}\text { Piring } \\
\text { (bamboo } \\
\text { plate) }\end{array}$ & $\begin{array}{c}\text { Tikar } \\
\text { (bamboo } \\
\text { plaited } \\
\text { mats) }\end{array}$ \\
\hline $\begin{array}{c}\text { Gatot } \\
\text { (made } \\
\text { of } \\
\text { cassava } \\
\text { ) }\end{array}$ & $\begin{array}{l}\text { Wedang } \\
\text { Jahe } \\
\text { (hot } \\
\text { ginger) }\end{array}$ & $\begin{array}{l}\text { Lurik } \\
\text { (shirt } \\
\text { for } \\
\text { Male) }\end{array}$ & $\begin{array}{c}\text { Madya } \\
\text { (between } \\
\text { buyers } \\
\text { and } \\
\text { sellers) }\end{array}$ & $\begin{array}{l}\text { teak tree } \\
\text { leave }\end{array}$ & $\begin{array}{l}\text { Sendo } \\
\mathrm{k} \\
\text { (wood } \\
\text { en / } \\
\text { banana } \\
\text { leave } \\
\text { spoon) } \\
\end{array}$ & $\begin{array}{c}\text { Sendok } \\
\text { (wooden } \\
\text { / banana } \\
\text { leave } \\
\text { spoon) }\end{array}$ & $\begin{array}{c}\text { Kursi } \\
\text { (wooden / } \\
\text { bamboo } \\
\text { chair) }\end{array}$ \\
\hline $\begin{array}{l}\text { Grontol } \\
\text { (made } \\
\text { of } \\
\text { corn) }\end{array}$ & $\begin{array}{c}\text { Beras } \\
\text { Kencur } \\
\text { (hot rice } \\
\text { and } \\
\text { curcuma } \\
\text { ) }\end{array}$ & $\begin{array}{c}\text { Jarik } \\
\text { (skirt } \\
\text { for } \\
\text { Male/ } \\
\text { Female) }\end{array}$ & $\begin{array}{l}\text { Krama } \\
\text { (between } \\
\text { buyers } \\
\text { and } \\
\text { sellers) }\end{array}$ & $\begin{array}{l}\text { coconut } \\
\text { leave }\end{array}$ & $\begin{array}{l}\text { Gelas } \\
\text { (wood } \\
\text { en } \\
\text { /bamb } \\
\text { oo } \\
\text { mug) }\end{array}$ & $\begin{array}{l}\text { Gelas } \\
\text { (wooden } \\
\text { / bamboo } \\
\text { mug) }\end{array}$ & $\begin{array}{c}\text { Meja } \\
\text { (wooden / } \\
\text { bamboo } \\
\text { table) }\end{array}$ \\
\hline $\begin{array}{c}\text { Tiwul } \\
\text { (made } \\
\text { of } \\
\text { cassava } \\
\text { ) }\end{array}$ & $\begin{array}{l}\text { Wedang } \\
\text { Ronde } \\
\text { (hot } \\
\text { ginger } \\
\text { and } \\
\text { gluten } \\
\text { ball }\end{array}$ & $\begin{array}{l}\text { Kebaya } \\
\text { (blouse } \\
\text { for } \\
\text { Female) }\end{array}$ & $\begin{array}{l}\text { Krama } \\
\text { Inggil } \\
\text { (for } \\
\text { noticeme } \\
\text { nt board) }\end{array}$ & $\begin{array}{c}\text { bamboo } \\
\text { leave }\end{array}$ & $\begin{array}{l}\text { Cangki } \\
\text { r } \\
\text { (wood } \\
\text { en } \\
\text { /bamb } \\
\text { oo } \\
\text { cup) }\end{array}$ & $\begin{array}{c}\text { Cangkir } \\
\text { (wooden } \\
\text { / bamboo } \\
\text { cup) }\end{array}$ & $\begin{array}{c}\text { Bangku } \\
\text { (wooden / } \\
\text { bamboo } \\
\text { bench) }\end{array}$ \\
\hline
\end{tabular}

\subsection{Discussion}

From the 4 (four) Javanese traditional food, (1) Gati is a sweet snack made of sesame with brown sugar, (2) Gatot is a snack made of cassava with shredded coconut, (3) Grontol is a snack made of boiled corn with shredded coconut, and (4) Tiwul is a sweet snack made 
of cassava with brown sugar. Meanwhile, from the 4 (four) Javanese traditional beverage names, (1) Bajigur is a hot drink made of ginger, coconut milk and brown sugar, (2) Wedang Jahe is a hot drink made of ginger with brown sugar, (3) Beras Kencur is a hot drink as as a herbal medication for fatigue made of rice, curcuma and brown sugar, and (4) Wedang Ronde a hot drink made of ginger, gluten ball filled with nut, sugar palm fruit, nut, and brown sugar. Those food and beverages are served at the market to preserve the old but unique Javanese traditional culinary so that the Javanese young generation understand their traditional culinary and experience the taste themselves at the market.

From the 4 (four) Javanese traditional clothing, (1) Blangkon is a headpiece for male made of batik cloth, (2) Lurik is a striped (lurik) shirt for male or blouse for female, (3) Jarik is a cloth to cover male and female waist to toe made of batik resembling a skirt, and (4) Kebaya is a blouse for women. There is also another formal men clothing on the market named Beskap which is commonly used in formal ceremony. All sellers is obliged to wear those traditional Javanese clothing to let the Javanese young generation know their traditional clothing and see how it look. It is hoped that they were inspired to wear those kind of clothing in their daily or special day.

From the 3 (three) Javanese language politeness) levels, (1) Ngoko is used among sellers as they were in the same social status level as sellers, (2) Madya is used between buyers and sellers as sellers consider young or same aged buyers to have a higher level than sellers, (3) Krama is used between buyers and sellers in which buyers are older than sellers, and (4) Krama Inggil is used on the noticement board made by the market management for the visitors as they honor them. For example:

When two sellers talk each other, they use Ngoko since they were at the same age and their position is equalas seller.

Seller 1 : Kowe entuk duwit piro? (how much money did you get today?)

Seller 2 : Aku dino iki entuk rong atus ewu. (today I got two hundred thousand rupiah)

When a seller and a buyer talk each other, the buyer use Madya and the seller use Krama since the seller honor the buyer eventhough the buyer.

Buyer : Niki regane pinten? (how much is it?)

Seller : Niki regine gangsal ewu. (it is five thousand rupiah)

Buyer : Limang ewu? (five thousand rupiah?)

Seller : Nggih gangsal ewu. (yes five thousand rupiah)

Sometime, buyer also use Krama when seller is older than buyer.

Buyer : Niki nopo namine? (what is it?)

Seller : Niki gatot mbakyu. (this is gatot sister)

Buyer : Manis mboten? (sweet?)

Seller : Mboten patos manis kok mbakyu. (not too sweet sister)

For noticement board, the market management use Krama Inggil as formal form such as lintu arto (money changer), nyuwun kawigatosanipun (attention please), papan menika saking plastik (this place is plastic free), arto kedhah dilintu koin (regular money must be changed into coin made of wood), sesarengan njagi karesikan lingkungan (let us together keep the environment clean), placaton ngginaaken boso Jowo (talk in Javanese), mbucal wuh wonten papanipun (do not litter), and sugeng rawuh (welcome).

There is a unique Javanese culture representing their local wisdom of using the abundant, available and eco-friendly natural resources that is wrapping the food using leavessuch us (1) banana leaves for grontol, (2) teak tree leaves for take home snack, (3) cococut leaves for lepet, and (4) bamboo leaves for tempeh. Those kind of wrapping teach Javanese young generation to take care of their environment by replacing the use of plastic and paper wrapping with natural wrapping like those leaves. This local wisdom can be spread throughout the nation to face the global problem of plastic trash. 
Another Javanese local wisdom of using natural resources that are the eating utensils for serving food and beverage to buyers and foodware to display the food and beverage for sellers as the sellers use (1) bamboo plate, (2) wooden or banana leave spoon, (3) wooden or bamboo mug, and (4) wooden or bamboo cup. Those eating utensils and foodware also teach Javanese young generation to take advantage of their natural resources and take care of their environment by replacing the use of plastic and paper eating utensils and foodware with natural ones like wood and bamboo. This local wisdom can also be spread throughout the nation to face the global problem of plastic trash

As Java Island is famous of its abundant natural resources like wood and bamboo used as furniture, Javanese traditional furniture also found in the market to serve visitors who want to enjoy the food and beverage on the spot. They are (1) bamboo plaited mat for sitting on the ground, (2) wodeen or bamboo chair, (3) wooden or bamboo table, and (4) wooden or bamboo bench. Beside teaching Javanese young generation to take advantage of their natural resources and take care of their environment by replacing the use of plastic and furniture with natural ones like wood and bamboo, this kind of furniture becomes the pride of Javanese people like Jepara furniture with its beautiful engraving. This local wisdom has already become a famous business commodity throughout the world.

\section{Conclusion}

From the finding and discussion, the researcher found out that both the local people and the local government of Dhoplang Javanese Traditional Culinary Market, Desa Pandan, Kecamatan Slogohimo, Kabupaten Wonogiri had already put their best effort to maintain their Javanese culture and language and even involving visitors who are not only coming from Java or having Javanese background to feel the traditional Javanese athmosphere and join the vibe. It shows that if the owner of a culture and the speaker of a language put their best effort to keep their culture and language, both of them will not be shifted, replaced, endangered, extinct or dead. In fact, their culture can be kept, maintained, preserved and even be spread throughout the world.

\section{References}

1. J. Holmes. An Introduction to Sociolinguistics. New York: Longman, 56 (2001)

2. W. Sundari. Preserving Javanese Culture by Junior Highschool Students in Northern Semarang District as Javanese Language Environment to Promote Local Tourism Industry. in Proceedings of the International Conference on Energy, Environment, Epidemiology, and Information System (ICENIS), 7-8 August 2019, Semarang, Indonesia (2019).

3. Sugiyono. Metode Penelitian Kualitatif dan R\&D. Bandung: CV Alfabeta, 45 (2010)

4. Sudaryanto. Metode dan Aneka Teknik Analisis Bahasa. (Pengantar Penelitian Wacana Kebudayaan secara Linguistik). Yogyakarta: Duta Wacana, 145 (1993)

5. Koentjaraningrat. Pengantar Ilmu Antropologi. Rineka Cipta. Jakarta, 203-204 (2000)

6. R. Fasold. Sociolinguistics of Language. Oxford: Blackwell, 213-214 (1994)

7. R. Wardaugh. An Introduction to Sociolinguistics. Massachusetts: Cambridge, 2 (2015) 